University of Warwick institutional repository: http://go.warwick.ac.uk/wrap This paper is made available online in accordance with publisher policies. Please scroll down to view the document itself. Please refer to the repository record for this item and our policy information available from the repository home page for further information.

To see the final version of this paper please visit the publisher's website. Access to the published version may require a subscription.

Author(s): Simon Clarke, Lena Varshavskaya, Sergei Alasheev and Marina Karelina

Article Title: The Myth of the Urban Peasant

Year of publication: 2000

Link to published version:

http://dx.doi.org/10.1017/S0950017000000283

Publisher statement: None 


\title{
The Myth of the Urban Peasant
}

\section{Simon Clarke}

University of Warwick and Institute for Comparative Labour Relations Research, Moscow

\section{Lena Varshavskaya}

Institute for Comparative Labour Relations Research, Kemerovo

\section{Sergei Alasheev and Marina Karelina}

Institute for Comparative Labour Relations Research, Samara

\begin{abstract}
AвSTRACT This paper explores, the 'myth of the urban peasant', the widespread belief that urban Russian households are surviving the collapse of employment and money incomes by turning to subsistence agriculture. On the basis of the analysis of official and survey data the paper shows that although many urban households grow food in their garden plots, those with low money incomes are the least likely to do so, while subsistence production is a complement rather than an alternative to paid employment. Moreover, those who do grow their own food work long hours for very little return, spending no less of their money income on buying food than do those who grow nothing. The implication is that dacha use is a leisure activity of the better-off rather than a survival strategy of the poor. Regional data suggests that urban agricultural production persists in those regions in which commercial agriculture and monetised relations are least developed which, it is surmised, retain memories of past shortages
\end{abstract}

By the end of 1998 the average money income of Russian households had fallen to the level of 1970, a decline of two-thirds since 1990. Employment had fallen by around 25 per cent, with a further 5 per cent laid-off at any one time, and the real value of wages and pensions had fallen to less than half the 1985 level, while survey data indicated that only a quarter of those employed were actually receiving their wages in full and on time (Clarke 1999a; Clarke 1998). Such a dramatic and sustained fall in money incomes raises the question: how do Russian households survive? While there has been very little systematic research into the survival strategies of

Simon Clarke is Professor of Sociology at the Centre for Comparative Labour Studies, University of Warwick and Scientific Director of the Institute for Comparative Labour Relations Research, Moscow. Lena Varshavskaya is Senior Research Fellow at the Institute for Comparative Labour Relations Research, Kemerovo. Sergei Alasheev and Marina Karelina are Senior Research Fellows at the Institute for Comparative Labour Relations Research, Samara. 
Russian households (Clarke 1999b), the image conveyed by the Russian and foreign media is that the population survives through its heavy involvement in the 'hidden economy'. While the proponents of reform portray an image of a population exploiting new opportunities as freelance consultants and market traders, the most common media image is of impoverished families eking out an existence on their garden plots, or standing by the roadside trying to sell some of their meagre crop. This image is not merely an innocent matter of the popular imagination, it also guides public policy. Under the World Bank's \$80o million Social Protection Adjustment Loan, announced in June 1997, the Russian government introduced trials of three new forms of provision of social assistance based on the assessment of the potential rather than the actual income of the household, which included access to land as a criterion for disqualification from receipt of social assistance (Clarke 1999c). However, while rural residents have always produced much of their own food in Russia, the widespread belief that the mass of the urban population has returned to subsistence farming, the 'myth of the urban peasant', has not been subjected to critical examination. ${ }^{1}$ In this article we intend to review our own and other data in order to ask how valid is the popular image of subsistence agriculture as the core of the survival strategies of impoverished urban households? ${ }^{2}$

Those who believe that self-sufficiency is becoming the rule rather than the exception in Russia can find powerful support from the official statistics, according to which well over half of the total amount of food by value produced in Russia is grown on the garden plots of the population, up from only one quarter in 1990. However, these figures are very misleading for two reasons. First, the growing proportion of food produced on domestic plots is more a result of the decline in production on state and collective farms (Wegren 1998), the value of which at constant prices has fallen by well over half since 1990, than of the growth of domestic production, which grew by 17 per cent in value terms between 1990 and 1992, but has not actually increased since then.

Second, and much more important, the category of domestic production (khozyaistvo naseleniya) combines household subsistence production with almost all smallholding agriculture, including the 'personal subsidiary agriculture' ( $L P K h)$ which supplied a substantial proportion of farm produce in the Soviet period. Although the peasants claimed ownership of the individual animals, they were almost all raised on the land of the state and collective farms and fed with fodder supplied by the farms. This is how these plots are able to perform the apparently remarkable feat of producing half the meat, wool and milk produced by the whole agricultural sector on only 2 per cent of the total area under pasture. Thus, the official data can tell us very little about the role of subsidiary agriculture in the survival strategies of urban families.

This is not to say that land is not widely owned and widely used in Russia. According to the 1994 microcensus, 58.3 per cent of all households had a plot of land 
and even in the cities of Moscow and St Petersburg, 21 per cent and 27 per cent respectively had plots of land. Most of those who have plots of land grow food on it. Thus, two-thirds of all households, including half the urban households, in the Russian Longitudinal Monitoring Survey (RLMS) grew some of their own food in 1998. However, the official household budget survey data indicate that the scale of self-sufficiency among urban families is much less than the agricultural production statistics would suggest. Although in the countryside 45 per cent of food by value was home grown in 1997 and 40 per cent in 1998, in the urban areas the figures were far lower: 9 per cent of food by value was home grown by urban families in 1997 and 8 per cent in 1998 (the second quarter of 1999 showed a further small decline over the second quarter of 1998, despite the crisis of autumn 1998). These figures include not only large cities, but also small towns. In Moscow and St Petersburg, which together account for 12 per cent of the urban population of Russia, virtually nothing was home-grown. It would seem that, while self-sufficiency may well be a feature of rural existence in Russia, and those in smaller towns may produce a significant proportion of their food for themselves, the dependence of city dwellers on their garden plots is much less than is generally imagined.

Of course, averages can conceal a multitude of variations. To discover who uses the land and what they use it for we have to analyse the household survey data in more detail. Just over half the households in the ISITO survey said that they used a plot of land, although this varied between one-third in Lyubertsy, half in Samara, 58 per cent in Syktyvkar and two-thirds in Kemerovo. ${ }^{3}$ We did not ask the households to detail exactly how much of each crop they produced, but only to estimate what proportion of their needs for potatoes, vegetables, fruit, dairy products and meat they met through buying, what proportion through their own production and what proportion was given to them by others. It turned out that the majority of households in each case either bought all or none of the relevant product, with most of the rest buying around half their needs of that product. Households produced virtually none of their own meat and dairy produce.

The fact that the ownership of land and the self-provisioning of the household is by no means universal, and that they vary considerably from one city and one region to another, raises the questions of why some people use land and others do not, of why some people use their land to grow their own food and others do not. Is the dacha means by which households with a low money income manage to meet their basic subsistence needs? Is it an alternative to waged employment as an element in a particular type of household survival strategy? Is it a cultural hangover from the peasant past? These are the questions that will be addressed in the rest of this paper.

\section{Deciding to Use a Dacha}

To grow food, it is necessary to have access to a plot of land. The large-scale 
use of subsistence plots by city residents is not a legacy of Russia's peasant past. Plots were distributed to city dwellers to enable them to feed themselves during the war, and there was a further mass distribution of land to urban households at the end of the 1980s. About the same time, enterprises began to rent fields on which their employees could grow potatoes, even providing transport and adapting the rhythm of industrial production to the demands of potato cultivation. Half our dachniki had started using their land in the last ten years. Although many people have a dacha because they have always had one, according to the RLMS data there appears to be a significant turnover among the dachniki, at the rate of between 10 and 15 per cent of land users each year. As we will see, the use of a dacha to produce food involves quite a considerable expenditure of time, effort and, in many cases, money. It is therefore reasonable to regard the use of a dacha as the result of a positive decision taken in the light of the current status and situation of the household and its members.

The hypothesis that we wish to explore is that the use of a dacha is a means by which households secure their food supplies in the face of a shortage of money. If this was the case, we would expect lower-income households to be more likely to use a dacha. We would also expect paid employment and work on the dacha to be competing uses of time: those who can do so will be more likely to work to earn the money to buy their food rather than to work the land, and the higher their wages the less likely we would expect them to be willing to do so. We would especially expect those with second jobs to be less likely to work on the land.

In the context of the Russian crisis many people find themselves in employment which generates only a reduced income or no income at all. We would expect those households which are deprived of money income by the non-payment of wages, by lay-offs or by short-time working to be more likely to have to acquire and work a dacha in order to meet their basic subsistence needs. We would expect those subject to lay-offs and short-time working to be more likely to work the land since they will have more free time than those still working but not being paid their wages.

We would expect that the larger the household and the more household members are not in paid employment, the more likely would the household be to work a dacha. We would expect the alternative opportunities of household members to be less the lower the level of education of household members. It is also reasonable to expect that pensioners, particularly those who are no longer working, have fewer opportunities of engaging in paid employment. Children are proscribed by law from working in paid employment, but they can make a significant contribution to working the dacha.

Self-provisioning with food is not simply a matter of desire, but also of capacity and opportunity. Although we would expect those with lower money incomes to be more inclined to produce their own food, to engage in domestic production households also need at least the minimum of resources (tools, seeds, fertiliser, pesticides) required for cultivation. On this basis, despite our expectation that those 
with lower incomes will be more likely to grow their own food, it may be that households in the lowest income groups will be less likely than those above a certain income threshold to use a dacha. Similarly, we would expect those households with their own means of transport to be more likely to use a dacha. Finally, producers also need a certain amount of skill and expertise, as well as the physical capacity, to do the necessary work. The latter consideration would lead us to expect that households of a rural origin will be more likely to use a dacha and households of old people will be less likely to use a dacha.

Running a series of logistic regressions in all three data sets, we find that the hypotheses relating to the opportunity to use a dacha are more or less strongly supported, the most important being the demographic composition of the household: the more adult members and the more pensioners there are in the household, the more likely it is to possess a dacha. ${ }^{4} \mathrm{~A}$ household based around a married couple is also substantially more likely to have a dacha. If the head of household is male, then the household is marginally less likely to have a dacha. Households with members born or brought up in a rural district are substantially more likely to have a dacha, and having an automobile is one of the strongest predictors of dacha ownership.

The age and education level of the head of the household is a strong and significant influence on the probability of having a dacha, but does not conform to our hypotheses. Those with higher levels of education are significantly more likely to have a dacha, which is contrary to the hypothesis that those with higher levels of education would have better alternative opportunities of earning a living and so would be less drawn to working the land. We might speculate that this is to do with the greater flexibility and ability to learn of those with higher levels of education, qualities which are needed for what is in effect adopting a new profession.

Having children also increases the likelihood of having a dacha, even pre-school children who need childcare being no barrier to dacha use. We also find that households headed by the over-forties are much more likely to have a dacha than those headed by prime-age men or women. Although age is not much of an impediment to working a dacha, disability is more so, households with members with invalidity pensions being less likely to work a dacha.

All the hypotheses considered so far are more or less uncontroversial, but they are all subsidiary to the central argument under consideration since none of them relate to the relationship between dacha use and household income and employment. When it comes to the critical set of variables, the picture is much less clear. In our own survey there is no significant functional relationship between income and use of a dacha. The RLMS data shows dacha ownership being the lowest at the ends of the income scale and highest in the middle, although only at the top is the difference statistically significant and such an effect is likely to be a result of aggregation since larger cities have higher incomes and lower dacha use. In both of these data sets the standard errors of the income coefficients are very high, indicating that there is no 
clear relationship between income and dacha use. The relationship between income and dacha use in the 1994 micro-census data is not consistent across regions. Nevertheless, in this data dacha ownership is certainly not a decreasing function of income. All of this data leads us to reject the fundamental hypothesis that the dacha functions primarily as a means by which the more impoverished households provide their own subsistence.

The variables that we have considered so far all relate to the greater or lesser possibility of growing food, without taking into account the alternative possibility of waged employment. One conclusion that stands out very clearly from all three data sets is that there is absolutely no evidence that working a dacha is regarded as an alternative to paid employment. The set of relevant hypotheses either find no support or are directly contradicted by the data.

In the ISITO data, wages and working hours in main or second jobs are not significant determinants of the probability of having a dacha. Nor is the number of household members who are working or the proportion of working members who have second jobs significant. In the RLMS data, the composition of income, the proportion of household members who are in work and the average number of hours spent in waged work are not significant determinants of the probability of dacha use, while the existence of secondary employment among household members significantly and quite substantially increases the probability of using land. The microcensus data provides no support for these hypotheses either. The number of household members earning a wage is the one variable that is completely insignificant in the all-Russian regression, despite the enormous size of the sample (1.7 million households). We seem to be drawn to the inescapable conclusion that the dacha is neither a means by which households with low money incomes compensate for their lack of spending power, nor are dacha ownership and waged employment alternatives. Thus, the use of a dacha cannot be explained as the result of household decisions to produce food in response to economic difficulties or limited employment opportunities.

\section{Why Do People Use Dachas?}

We should not jump to any conclusions prematurely. It may be that dacha use is more diverse, that different households use dachas for different reasons, and that this diversity has been concealed beneath statistics that lump everybody together. Perhaps for the poor the dacha is a source of subsistence, while for the better off it is a place of rest and relaxation.

In our household survey we asked people what were the two most important reasons for using their dacha. We also asked those who did not have a dacha why they did not have one. The responses are summarised in Table 1.

When we look at the mean household income of each group we find that there is 
Mean household income per head by main reasons for having or not having a dacha

\begin{tabular}{lccc}
\hline & $\begin{array}{c}\text { Percentage } \\
\text { citing as } \\
\text { main reason }\end{array}$ & $\begin{array}{c}\text { Mean } \\
\text { household } \\
\text { income per head }\end{array}$ & $\begin{array}{c}\text { Standard } \\
\text { error } \\
\text { of mean }\end{array}$ \\
\hline Hobby, leisure, we like it & 17 & 830 & 30 \\
Additional produce & 44 & 646 & 16 \\
Providing for a rainy day & 3 & 572 & 52 \\
Main source of subsistence & 36 & 519 & 14 \\
Total with a dacha & 100 & 629 & 10 \\
& & & 71 \\
We don't need it & 8 & 996 & 51 \\
We do not want to do it & 14 & 852 & 37 \\
We do not have time to do it & 15 & 800 & 21 \\
We cannot get any land & 18 & 548 & 13 \\
We do not have the money & 34 & 499 & 13 \\
Health reasons & 34 & 495 & 12 \\
Total without a dacha & 100 & 608 & \\
\hline
\end{tabular}

a significant gradation of income in very much the direction that we would expect. The subjective assessments of the importance of the dacha for the household subsistence for those who have a dacha also accord quite closely with the reasons given for having a dacha: Ninety one per cent of those who said that the dacha was their basic source of subsistence said that their domestic production was important in providing for the family, against 57 per cent of those who said the dacha was primarily a hobby. Among those who do not have a dacha we find a similar sharp distinction in mean incomes, between those who choose not to work a dacha: they did not want to, did not need to or did not have the time to do it, and those who are unable to work a dacha: they are in poor health, cannot get land or do not have enough money.

If we distinguish those dachniki who say that the dacha is a leisure activity from those who say it is a way of producing their household's basic means of subsistence, we can run our regressions separately for each category. At first sight, separating the different types of dacha owner sets everything to rights. In particular, owning a dacha as a hobby is a strongly increasing function of income, while owning a dacha as a means of producing for the household's basic subsistence needs is a strongly decreasing function of income. Although most of the coefficients are not statistically significant, those households which use the dacha as a hobby tend to be smaller, younger and better educated than those which use the dacha as a basic source of subsistence. The one blot is the most important one: we might have expected those in employment to be more likely to use a dacha as a form of leisure both because these 
people are more likely to have the money to travel to and to maintain their dacha and because they are more likely to feel the need for a break after their working week. However, it turns out that there is no significant difference in the number of workers and the proportion engaged in secondary employment between those households which have a dacha as a hobby and those households which have it as their basic means of subsistence.

Moreover, what people say does not necessarily correspond to what they do. Ninety-nine per cent of subsistence producers say that they grow some of their own food, but so also do 93 per cent of the hobbyists. Those who work the land because they enjoy it do not work any less hard: there is no significant difference in the number of hours worked on the land by household members whatever they said was their motive for doing so. Nor does it mean that the production of food is unimportant to them: those who said that the dacha was their main source of subsistence grew more than those who said that they worked the dacha because they enjoyed it, but the only statistically significant difference is that in Samara and Lyubertsy hobbyists are relatively more likely to grow fruit than vegetables and potatoes so that, while they grow just as much of their fruit as do subsistence producers, they do produce substantially less potatoes and vegetables. This suggests that the motives people give may be as much a reflection of the image that the household seeks to uphold as of its actual motivation, with higher income and better educated households not wanting to identify themselves with subsistence production, while lower income and less educated households are more willing to elevate the traditional values of labour over the post-Soviet values of leisure. We clearly need to look more closely at what people actually do with their land.

\section{Dachas and the Domestic Production of Food}

What factors determine whether a household produces its own potatoes and vegetables rather than buying them in the market? In particular, is domestic production an expression of a particular survival strategy, adopted by particular households in particular conditions? This is the question that we have already explored in relation to the ownership of a dacha, on the not unreasonable assumption that the reason why people in Russia acquire land is to grow their own food. However, looking specifically at the domestic production of food gives us a different angle on the question and in principle provides more analytical scope because we can investigate not only whether or not households produce their own food but what and how much they produce.

In practice this scope is rather more limited than we might have hoped. On the one hand, very few households produce their own meat and dairy products and, in Kemerovo and Syktyvkar, even fruit. On the other hand, the tendency is for households to buy either all or none of their basic foodstuffs (18 per cent of households 
produced all and 34 per cent bought all of their potatoes and vegetables), most of the remainder saying that they produced half their needs. This distribution of outcomes makes it inappropriate to examine the production of food by taking the per centage of each product grown as the dependent variable in a linear regression. Instead we ran a series of logistic regressions in which the dependent variable was the probability of growing at least 50 per cent of the household's needs for the specific kind of product (although the results did not turn out very different from the equivalent linear regressions). ${ }^{5}$

The results of this exercise (summarised in Table 2) are to reinforce our earlier conclusions: the determinants of the likelihood of growing food on the dacha are almost identical to the determinants of ownership of a dacha in the first place. The younger and better educated households, those who have higher incomes and better earning and employment opportunities, may say that they work the dacha as a hobby, but they nevertheless put in a lot of work and produce a lot of potatoes, vegetables and fruit.

It is not the poor who grow their own food: households with the lowest incomes are the least likely to produce their own potatoes and vegetables, indicating that opportunity is more powerful than need in motivating self-sufficiency in basic foodstuffs. ${ }^{6}$ This is confirmed by subjective indicators: those who say that they do not have enough money even to buy food are also significantly less likely to grow their own potatoes, so domestic production does not provide a lifeline for the poor. Nor does domestic production have more than marginal significance for the relief of temporary hardship: the existence and extent of administrative leave, wage delays and short-time working all have no statistically significant impact on the probability of the household producing any of its own food (with the marginal exception of fruit-growing for those working short-time).

Those who are most likely to grow their own food are the households usually considered to be least at risk of poverty - a household with two working-age adults and no children. If the household also has co-resident pensioners, whose pensions are the most reliable source of money income in Russia, the household becomes even more likely to grow its own food. As in the case of dacha ownership, the most important resource that facilitates the domestic production of food is ownership of private transport: those with a car or motorbike are on average twice as likely to grow their own food as those without. Moreover, car ownership has its biggest impact on families with a low money income, low-income families with a car being well over twice as likely as those without a car to produce their own food. ${ }^{7}$ It seems that rather than being the last resort of those on the brink of starvation, domestic agricultural production provides an additional form of security for those who are already quite well placed to weather the storm.

As in the case of the ownership of a dacha, there is absolutely no indication in the data that domestic production is an alternative to earning money in order to meet 
Table 2

Logistic regressions: probability of home-production of at least 50 per cent of consumption of various products

\begin{tabular}{|c|c|c|c|c|c|c|}
\hline \multirow[b]{2}{*}{ Variable } & \multicolumn{3}{|c|}{ Potatoes } & \multicolumn{3}{|c|}{ Vegetables } \\
\hline & B & $\mathrm{SE}(\mathrm{B})$ & $\operatorname{Exp}(B)$ & B & $\mathrm{SE}(\mathrm{B})$ & $\operatorname{Exp}(B)$ \\
\hline No. of children under 7 & -0.1372 & 0.1079 & 0.8718 & -0.0606 & 0.1036 & 0.9412 \\
\hline Number of children 8-15 & 0.0664 & 0.0718 & 1.0687 & 0.1218 & 0.0688 & 1.1296 \\
\hline Number of working age & 0.1059 & 0.0633 & 1.1117 & 0.0494 & 0.0603 & 1.0507 \\
\hline Number of pension age & 0.2535 & 0.0911 & $1.2886^{* *}$ & 0.3853 & 0.0866 & $1.4700^{\star *}$ \\
\hline Number in work & 0.1155 & 0.0760 & 1.1224 & 0.0296 & 0.0724 & 1.0300 \\
\hline \multicolumn{7}{|l|}{ Proportion of workers with } \\
\hline second jobs & -0.0567 & 0.1609 & 0.9449 & -0.1821 & 0.1562 & 0.8335 \\
\hline Is there a spouse? & 0.3420 & 0.1003 & $1.4078^{\star *}$ & 0.3874 & 0.0957 & $1.4731^{\star \star}$ \\
\hline Male-headed & -0.0852 & 0.0977 & 0.9183 & -0.2372 & 0.0946 & $0.7888^{\star}$ \\
\hline Household head under 25 & 0.1323 & 0.1849 & 1.1414 & 0.2436 & 0.1805 & 1.2758 \\
\hline Household head 40-59 & 0.4191 & 0.1113 & $1.5205^{* *}$ & 0.5120 & 0.1074 & $1.6686^{\star *}$ \\
\hline Household head 60 and over & 0.4456 & 0.1707 & $1.5614^{\star *}$ & 0.3303 & 0.1629 & 1.3914 \\
\hline Education of head of household & 0.0578 & 0.0308 & 1.0595 & 0.0559 & 0.0293 & 1.0574 \\
\hline \multicolumn{7}{|l|}{ Household members of } \\
\hline Household has a car or motorcycle & 0.9026 & 0.0971 & $2.4660^{\star *}$ & 1.0629 & 0.0921 & $2.8946^{* *}$ \\
\hline $\begin{array}{l}\text { Average hours worked per } \\
\text { working member }\end{array}$ & 0.0007 & 0.0006 & 1.0007 & 0.0003 & 0.0005 & 1.0003 \\
\hline \multicolumn{7}{|l|}{ Days admin. leave per working } \\
\hline \multicolumn{7}{|l|}{ Wages owed per working member } \\
\hline R00s & 0.0042 & 0.0022 & 1.0042 & 0.0018 & 0.0020 & 1.0018 \\
\hline \multicolumn{7}{|l|}{ Days short-time per household } \\
\hline member & -0.0008 & 0.0015 & 0.9992 & 0.0009 & 0.0015 & 1.0009 \\
\hline \multicolumn{7}{|c|}{ Income quintiles (third quintile is reference) } \\
\hline First & -0.2850 & 0.1302 & $0.7520^{\star}$ & -0.2572 & 0.1237 & $0.7732^{*}$ \\
\hline Second & -0.1872 & 0.1209 & 0.8292 & -0.1783 & 0.1148 & 0.8367 \\
\hline Fourth & -0.3841 & 0.1241 & $0.6810^{\star *}$ & -0.2992 & 0.1180 & $0.7414^{*}$ \\
\hline Fifth & -0.2763 & 0.1292 & $0.7586^{*}$ & -0.2370 & 0.1236 & 0.7890 \\
\hline Ratio of wage to total income & 0.0274 & 0.1841 & 1.0278 & 0.0965 & 0.1764 & 1.1013 \\
\hline Proportion of income spent & & & & & & \\
\hline on food & 0.0147 & 0.0410 & 1.0148 & -0.0221 & 0.0412 & 0.9781 \\
\hline Kemerovo & 2.0585 & 0.1051 & $7.8345^{\star *}$ & 0.9196 & 0.0957 & $2.5083^{* *}$ \\
\hline Syktyvar & 1.4494 & 0.1084 & $4.2606^{\star *}$ & -0.0757 & 0.1044 & 0.9271 \\
\hline Lyubertsy & -0.3833 & 0.1208 & $0.6816^{\star *}$ & -1.1216 & 0.1164 & $0.3257^{* *}$ \\
\hline Constant & $-2.6158^{\star \star}$ & 0.2197 & & $-1.7406^{\star *}$ & 0.2048 & \\
\hline Number of households & 3782 & & & 3782 & & \\
\hline$-2 L L$ & 4080 & & & 4390 & & \\
\hline Model Chisq & $1010^{\star *}$ & & & $685^{\star *}$ & & \\
\hline
\end{tabular}

${ }^{\star}$ Significant at $0.95 ;{ }^{* *}$ Significant at 0.99 . 
basic consumption needs: neither the number of workers in the household, nor the average amount of time that they work nor the proportion of wages in total income, nor the proportion of household members who have second jobs is significant in determining the probability of the household producing its own food. Decisions about domestic food production would appear to be taken quite independently of decisions about paid employment.

This conclusion is not modified if we run separate regressions for those who work a dacha as a hobby and those who work the dacha as the main source of subsistence. The coefficients on the income and employment variables are perverse from the point of view of the hypotheses that we have been exploring, although none of them is statistically significant, partly because we have only about 700 cases for each regression.

\section{The Costs and Benefits of Domestic Food Production}

Before finally rejecting the hypothesis that working the dacha can be regarded as a productive activity governed by the norms of economic rationality, we should look a bit more closely at the economic rationality of the domestic production of food. What is the order of magnitude of the costs and the benefits involved in this activity? As we will see, the costs in both money and labour time can be quite substantial, while the benefits, in terms of the value of useful product, appear very meagre.

Even in money terms, 'subsistence production' can be a costly activity. Over three-quarters of households in the ISITO survey who were using their own land, rather than that of other relatives, had to pay something for the use of the land. Although the mean payment was less than 200 roubles a year, this is as much as a month's money income per head for the poorest households. Having paid for the land, there is the cost of tools, seeds, fertiliser and transport to be covered. Twenty per cent of those working dachas said that they had no money outlays at all, but of those who did, the mean monetary expenditure was 500 roubles per year. Moreover, this is almost certainly an underestimate: when a sample of Kemerovo households were asked first to estimate their total expenditure and then to enumerate it to achieve a more precise estimate, the result was an average of 20-30 per cent higher than the original estimate.

Working a dacha does not only involve household members. Almost a quarter of our dachniki use land belonging to friends and relatives, while in one in four of our households a non-member of the household plays at least one of the key roles in the process (making decisions about production, doing most of the work on the plot, processing the produce and, in rare cases, selling the produce). We asked the household head what proportion of the produce, if any, was given to friends or relatives. Over 60 per cent of households gave away an average of 30 per cent of the 
produce to others. However, the exchange of food is more complicated than this: one quarter of the households with dachas also received some food from other people, while one in six households which do not work a dacha were nevertheless in a position to give food to others: overall at least 14 per cent of households both gave and received food in the previous year.

On top of the monetary outlay, working a dacha can take up a considerable amount of time. Only one in ten adult members of households that had a dacha did not spend any time working on the land: the members of the average household that worked a dacha estimated that together they spent 860 hours per year working on their land. At the individual level, there is no difference in the hours worked in paid employment or in secondary employment between those with a dacha and those without, further clear evidence that working on the dacha is not a substitute for paid employment. Each employed household member who works on a dacha puts an average of an additional eighty-two hours of work per month into work on the land during the season, almost half as much as they work in their regular job. Nonworking adults put in, on average, exactly the same amount of work, while nonworking pensioners each put in an average of 120 hours a month. Moreover, 90 per cent of those working dachas have to travel to reach their plot. The mean return travel time was around ninety minutes in Kemerovo and Syktyvkar, two hours in Samara and almost four hours in Lyubertsy.

Work on the dacha does not have the same significance for men and for women. Male dachniki work an average of almost twenty hours per month more in their paid work than do female dachniki who are in paid employment, and male dachniki with a second job work on average three hours longer at that than do women, while the women work an average of four hours per month more on the dacha than do the men. However, while the men do an additional forty hours a month work around the home, the women spend an average of ninety hours a month on their domestic duties. Moreover, far from cutting back their domestic labour in order to devote more time to the dacha, women with a dacha do more domestic labour than those without, presumably because they are often having to maintain two homes, while men with a dacha do less, the differences being small but statistically significant. While the start of the dacha season marks the opening of a second labour front for men, for women it marks the opening of a third front.

If working the dacha is to be regarded as work, rather than as a leisure activity, then we should cost the labour time of the dachniki at the opportunity cost, which we can estimate at the hourly rate that those engaged in secondary employment earn in their second jobs, or the hourly rate in their primary jobs of those who have no secondary employment (this presumes that the latter have no opportunity to engage in secondary employment, which generally pays at a substantially higher rate). We have this data for just over half our dachniki households, which gives us an average imputed labour cost per household of just over 6,000 roubles per household per 
annum ( $\$ 1,000$ at the then current exchange rate), without accounting for travel time. This is very nearly a third of the total money income of these households.

What do people get for this enormous labour input? We did not ask our respondents to estimate the value or the volume of the output of their dachas, but we asked what proportion of their household's needs they satisfied. We also have the data of the Goskomstat budget survey on household consumption and expenditure on various categories of food, the data for St Petersburg and Moscow being most applicable since the patterns of consumption differ between large cities and rural districts. If we apply these figures to our own households we can derive a reasonably accurate estimate of the savings they make by producing their own foodstuffs. To this we must add the amount which some households received from the sale of their produce. If we deduct the amount that households (under-)report that they spend on their dacha, we find that the average net annual money return per head from working the dacha for those households which do so amounts to the princely sum of 125 roubles $(\$ 20)$, ranging from 3 roubles in Lyubertsy and 62 roubles in Syktyvkar to an annual gain of 165 roubles in Samara and 173 roubles in Kemerovo. To put this into perspective, even in the latter cities, this total return to a year's work on the dacha is about the monetary equivalent of one day's earnings in secondary employment.

Of course many of our dachniki may not have had the opportunity of undertaking additional paid employment. Another way of measuring the return to their labour would be to ask how successful is the use of the dacha as an element in the household's survival strategy? How much does the domestic production of food enable them to save out of the household budget? The most striking finding of all in our analysis of the data on domestic food production is that those who work a dacha spend exactly the same amount per head and exactly the same proportion of their money income on food as those who do not. This result applies overall and in each city separately and it applies however many other variables we control for. On this measure the gross return to working the dacha is nil: all that time and money is laid out without saving a kopeck on the household's food bills.

Other data confirms this finding for urban households. In the RLMS data, controlling for other variables, in the countryside and small towns those with a dacha spend a lower per centage of their income on food than those without a dacha, but the reverse is true in the cities. In the Goskomstat budget survey data we cannot separate out urban from rural residents, but even so, in a regression of the data for seventy-five regions there is no significant correlation between the proportion of potatoes home-grown in the region and spending on food as a proportion of total household expenditure, even when we control for the level of unemployment, the proportion of the population working in agriculture, the scale of non-payment of wages and the average real wage, the latter being the only variable in the regression that is at all significant, with the expected negative coefficient. It seems, therefore, 
that the RLMS and Goskomstat data are at least consistent with our finding that working a dacha does not lead to a reduction in food spending.

This should not really be so surprising, since the produce of the dacha is largely confined to the cheapest food products: potatoes, cabbage, carrots and onions, spending on which accounts for only a small part of the food bill for all but the poorest of families, and the poorest families cannot afford to work a dacha. However much of their vegetables they produce on their dacha, virtually all urban households have to buy all their bakery, meat and dairy products and, for the more prosperous, their processed and more exotic foods, for money in the market. According to the 1996 household budget survey data for Moscow and St Petersburg, potatoes and vegetables account for only about 8-9 per cent by value of the total food consumption of the residents of big cities, or less than 4 per cent of their total money spending. In our survey the average saving achieved by our dachniki amounts to 3 per cent of their total household income, or 6 per cent of their total household spending on food. This is about the same as the average household admits to spending on alcohol in the budget survey. Saving a few roubles by growing their own food gives the dachniki enough money to buy a box of chocolates or a few bottles of vodka and a bit of sausage for the weekend.

\section{The Myth of the Urban Peasant?}

We have seen that there is no evidence that the domestic production of food has been chosen by households as an alternative to acquiring the necessities of life by earning money and then purchasing them, nor that it is the last resort of those who do not have sufficient money income to buy their own food. The households with the lowest money incomes and in the greatest hardship are the least likely to grow their own food. Those with more working members, those who work longer hours in their main jobs, those who are engaged in secondary employment are certainly no less and if anything are more likely to engage in subsidiary agricultural activity. Those who engage in subsidiary agriculture do not work any shorter hours in their primary and secondary employment than those who do not. The monetary saving achieved through such engagement is miniscule, particularly when measured against the enormous labour input. Finally, those who grow their own basic foodstuffs spend no less on food and food products than those who do not. All of the evidence would indicate that working the dacha is primarily a leisure activity, that people do it as a form of relaxation to give them a break from their working lives, and indeed almost half of all our dachniki cited this as one of the two reasons given for working their dacha. The fruit and vegetables that they produce is then merely a by-product, no more essential to their subsistence than is the product of the vegetable plot of any keen gardener. Many people say that they grow their own fruit and vegetables 
because that is the only way that they can get high quality produce or can be confident that it is ecologically pure.

However, that is not the end of the story. We still have to explain why this practice is so prevalent in Russia, why around half the urban population engages in it, despite the enormous costs and inconvenience involved, especially when the plots are often so far from home. To bring out the real significance of subsistence agriculture we should return to the point that stands out most clearly from our data, that the most striking difference is between the different cities.

The obvious explanation would refer to the depth of the economic crisis, although we have found it difficult to relate subsistence agriculture to any of the indicators of crisis at the level of the individual household. Moreover, unemployment rates, real wage levels and degrees of income inequality are not substantially different across our four cities. Administrative leave and short-time working are about twice as common in Samara and Kemerovo, which have seen a collapse of their military-related industrial base, as in Syktykar and Lyubertsy, and yet the incidence of subsistence agriculture cross-cuts these pairs of cities.

It is not a matter of the existence of favourable conditions for agriculture since it is the regions with the most unfavourable climate, sub-Arctic Syktyvkar and Kemerovo in Western Siberia, which have the most highly developed domestic agricultural production (although reported yields per hectare in growing potatoes and vegetables are highest in the Komi Republic and Moscow oblast and lowest in Samara, with Kemerovo in the middle). Rather than being the paradox that it appears at first sight, however, this may be part of the key to the explanation, for these are the regions with less developed commercial agriculture, and so in which supplies of even the most basic foodstuffs have historically been precarious. There have long been active and well-supplied kolkhoz markets in Central Russia and in the Volga region, so that at least since the late 1950 s people have been able to count on being able to buy their basic foodstuffs in the markets, even if the shops were bare. This was never the case in Siberia and in the Arctic, and in the late eighties supplies were as unpredictable as ever. ${ }^{8}$ This was the time at which large amounts of uncultivated land were distributed to urban residents in precisely these regions so that they could assure their supplies of basic foodstuffs by growing their own. Thus, the desire to produce one's own vegetables is perhaps not a reflection of the poverty of the household but of the limited development of the market in the region in question.

The fear that people have today is not so much that they will not individually have enough money to buy potatoes, although this is a fear that still haunts everyone, but that there will be no potatoes available to buy for any kind of money. Shortages and local famines remained a regular feature of life in the more remote regions well into the 1950s. It was the recurrence of shortages of basic goods that was one of the sparks that lit the fire of revolt in the late 1980s. Very few respondents cited such insecurity as a motive for growing their own food (Table 1), but our presumption is 
that this is a factor that acts at the collective level, sustaining or eroding the cultural tradition as those in regions with secure food supplies question the habits of the past as they cram into the bus or sit in the Friday evening traffic jams, trying to reach their garden plot.

Our hypothesis is that anxiety about the availability of food supplies relates not so much to the risk of shortages of supply as a result of the limited development of agricultural production, as to the risk of shortages resulting from failures in the system of distribution arising, on the one hand, as a result of the limited development of a market in agricultural produce and, on the other, as a result of the demonetisation of the regional economy. Thus, while Kemerovo and Samara have been hit equally by the recession, as indicated by the incidence of administrative leave and short-time working, it is Kemerovo and Syktyvkar that have been hit hardest by demonetisation of the economy: the average wage debt in Syktyvkar is more than twice that in Kemerovo, and four times that in Lyubertsy or Samara. One in five have been paid in kind in Syktyvkar and one in three in Kemerovo, but fewer than one in twenty in Lyubertsy or Samara. Although these phenomena have no impact on the probability of the individual household growing its own food within each region, they are indicative of the degree of demonetisation of the regional economy that provides an incentive for all but those with the highest money incomes to grow their own food, rather than to risk relying on having to buy in a market in which they may not have the means with which to buy. The correlation coefficient between the average total household wage debt and the per centage of potatoes home-produced in each of the four cities is 0.97 - for an exponential relation it is 0.996 .

Of course with only four cases the correlation could be spurious. To test the hypothesis more rigorously we can turn to the published Goskomstat data on the domestic production of potatoes derived from the 1996 household budget survey. Running a regression on this data, with a series of independent variables and controls (regional data taken from Goskomstat 1998), is at least supportive of the argument that the most important factor underlying the domestic production of food is the fear of market failure as a result of the demonetisation of the regional economy. Just as we found in our analysis of the household-level data, it does not appear that households are more likely to grow their own potatoes in regions in which wages are lower or the degree of income inequality or level of unemployment is higher, but the variables related to the demonetisation of the economy are statistically significant and their coefficients are in the expected direction: the higher the level of unpaid wages and the less extensive is the credit system the more are households likely to grow their own potatoes. These results are suggestive, but should certainly not be regarded as definitive because the data are fairly crude, and their interpretation is not unambiguous. Nevertheless, these variables are the most stable through a range of formulations of the regression.

The data that we have examined suggest very strongly that subsistence 
production does not provide an alternative to paid employment for those urban households who have suffered the most from the impact of the crisis, nor does it provide a means of survival for the most impoverished. Subsistence production is a cultural phenomenon whose economic function may at best be to provide an extremely inefficient way in which better-endowed households provide themselves with some security against the threat of a failure of food supply. While the use of a dacha may be a leisure activity that contributes to the health and vigour of the population (although amongst men it is strongly associated with drinking), its persistence should not foster a false sense of security among policy-makers nor should its encouragement be an object of social policy.

NOTES

1. An early review of survey data from various transition countries concluded that 'de-differentiation' and 'de-modernisation' had led to urban residents behaving like rural (Rose and Tikomirov, 1993). The authors of one of the very few serious publications on the subject reproduce without question the typical view that 'the majority of the population now produces its own food supply to a considerable extent' (Seeth et al.1998, p.1611).

2. The analysis draws primarily on the published data of the Russian Household Budget Survey and on three data sets. The Household Budget Survey is a monthly panel survey of the expenditure (and income until 1996) of a purportedly representative sample of just under 50,00o households, drawn from a frame derived from the 1994 microcensus returns (the somewhat idiosyncratic sampling method is described in Voprosy statistiki, 5, 1997). The results of the 1996 survey were published in a very limited edition in Ministry of Labour and Social Development and Goskomstat Rossii, 1997 and of the 1997 and 1998 and the second quarter of 1999 surveys, with some details of the methodology, in Goskomstat 1999a; Goskomstat 1999b; Goskomstat 1999c. The first data set is the 1994 microcensus, which was a survey of a 5 per cent sample of the whole population based on the 1989 census, in which, in addition to demographic details, respondents were asked about landholding and about the sources and size of household income. This data was supplied to us by Goskomstat and is now available on CD-ROM. The second is the second phase of the Russian Longitudinal Monitoring Survey, a panel survey of a stratified multi-stage allRussian sample of around 4,00o households which has been conducted in 1994, 1995, 1996 and 1998, in which respondents are asked in detail about landholding, their work on the land and the production, consumption and sale of a large number of food items. This data is available for downloading from the Carolina Population Centre of the University of North Carolina at Chapel Hill (www.cpc.unc.edu). The third is a survey of all adult members of a single-stage probability sample of 4,0oo households in four Russian cities (Samara, Kemerovo, Syktyvkar and Lyubertsy, a satellite city of Moscow), drawn from the computerised databases of the city population, that was conducted by the Moscow-based Institute for Comparative Labour Relations Research (ISITO) in April-May 1998. The survey was funded by the Department for International Development within the framework of a wider project funded by the Economic and Social Research Council, neither of which bodies is responsible for any of the views expressed in this paper. Details of the survey, sample evaluation and access to the data can be obtained from the project website, www.warwick.ac.uk/fac/soc/complabstuds/russia/. For earlier analysis of this data see Alasheev et al. 1999; Clarke 1999b; Yaroshenko 1999. 
3. Lyubertsy is a city on the Southeast fringe of the Moscow conurbation, Samara (population 1.3 million) is the regional centre of an economically diversified region on the banks of the Volga, Kemerovo (population half a million) is the centre of a heavy industrial region in Western Siberia, Syktyvkar (population quarter of a million) is the capital of the northern Komi Republic. Samara is a stronghold of liberal reform, Moscow city of neo-corporatism, Kemerovo of Communist counter-reformation and Syktyvkar of the continuity of administrative power. Apart from Syktyvkar, all four cities are well above average in the extent of the decline of industrial production and so in the extent of the employment restructuring they have undergone, but all are relatively prosperous against the background of Russia as a whole. All four are below average in the fall in living standards and in levels of reported unemployment and above average in the level of wages and the growth of the new trade and service sectors of the economy. Wage delays are well above average in Syktyvkar and Kemerovo and well below average in Samara and Moscow.

4. The detailed regression results are available in an earlier version of this paper from the project website at www.warwick.ac.uk/fac/soc/complabstuds/russia/dacha.doc.

5. These regressions are run for all households, the implication being that any household is able to acquire the land to grow food if it chooses and has the resources to do so. The RLMS data indicates that the turnover of dachniki is about 10-15 per cent per annum, so this is probably a reasonable assumption. The only significant variables in a regression run only for those who have a dacha are the regional dummies, rural origin and automobile ownership.

6. Seeth et al., p. 1620, also find that the lowest income quintile is the least likely to grow its own food. They conclude that the dacha is a means by which the middle and upper (though not the highest) income groups are able to increase their security rather than a source of subsistence of the poor.

7. It may well be that there is an historical dimension to this, in that low-income families with a car are more likely to have been relatively more prosperous at some time in the past, and so better placed to acquire and work a dacha.

8. In 1988 potatoes in the markets cost more than three times their price in the state shops, a higher premium than on any food other than dairy products (OECD-CEET 1991, p. 169).

REFERENCES

Alasheev, S., Varshavskaya, E. and Karelina, M. (1999) 'Podsobnoe khozyaistvo gorodskoi sem’i (Subsidiary agriculture of urban families)' in V. Kabalina and S.Clarke (eds.), Zanyatost' $i$ povedenie domokhozyaistv, Moscow: Rossiiskaya politicheskaya entsiklopediya (ROSSPEN).

Clarke, S. (1998) 'Trade Unions and the Non-Payment of Wages in Russia', International Journal of Manpower, 19 (1/2), 68-94.

Clarke, S. (1999a) The Formation of a Labour Market in Russia, Cheltenham: Edward Elgar.

Clarke, S. (1999b) New Forms of Employment and Household Survival Strategies in Russia, Coventry: Centre for Comparative Labour Studies.

Clarke, S. (1999c) 'Poverty in Russia', Problems of Economic Transition, 42, 5, September, 5-55.

Goskomstat (1998) Regiony Rossii, Moscow: Goskomstat Rossii.

Goskomstat (1999a) 'Osnovnye pokazateli vyborochnogo obsledovaniya byudzhetov domashnikh khozyaistv po Rossiiskoi federatsii v 1998 godu', Statisticheskii byulleten', 1(51) (March 1999), 9-182.

Goskomstat (1999b) 'Osnovnye pokazateli vyborochnogo obsledovaniya byudzhetov domashnikh khozyaistv po Rossiiskoi federatsii v 1998 godu', Statisticheskii byulleten', 5(55) (June 1999), $49-182$. 
Goskomstat (1999c) 'Osnovnye pokazateli vyborochnogo obsledovaniya byudzhetov domashnikh khozyaistv po Rossiiskoi federatsii vo II kvartale 1998-1999 godu', Statisticheskii byulleten', 11 (61) (November 1999), 113-88.

Ministry of Labour and Social Development and Goskomstat Rossii (1997) Monitoring of the Socio-Economic Potential of Families for the Fourth Quarter of 1996. Statistical Report, Moscow.

OECD-CEET (1991) The Soviet Agro-Food System and Agricultural Trade: Prospects for Reform, Paris: OECD-CEET.

Rose, R. and Tikomirov, E. (1993) Who Grows Food in Eastern Europe?, Glasgow: Centre for the Study of Public Policy.

Seeth, H. T., Chachnov, S. and Surinov, A. (1998) 'Russian Poverty: Muddling Through Economic Transition with Garden Plots', World Development 26 (9), 1611-1624.

Wegren, S. K. (1998) Land Reform in the Former Soviet Union and Eastern Europe, London and New York: Routledge.

Yaroshenko, S. (1999) 'Domashnie khozyaistva v usolviyakh perekhodnoi ekonomiki v Rossii: Tipy obespecheniya pitaniya v gorodskikh sem'yakh' in V. Kabalina and S. Clarke (eds.), Zanyatost' $i$ povedenie domokhozyaistv. Moscow: Rossiiskaya politicheskaya entsiklopediya (ROSSPEN).

Simon Clarke

Centre for Comparative Labour Studies

University of Warwick

WARWICK

Accepted January 2000

e-mail:Simon.Clarke@warwick.ac.uk 